\title{
The impact of cyclonic activity during 1981-1985 and 2004-2009 on taxonomic diversity of mollusks in the Gulf of Batabanó, Cuba
}

\author{
Actividad ciclónica en los periodos de 1981-1985 y 2004-2009 y su impacto sobre la diversidad taxonómica de los moluscos del \\ Golfo de Batabanó, Cuba
}

\author{
Norberto Capetillo-Piñar', José Espinosa Sáez², Arturo Tripp Valdez and Arturo Tripp Quezada' \\ ${ }^{1}$ Instituto Politécnico Nacional, unidad académica Centro Interdisciplinario de Ciencias Marinas (CICIMAR), IPN, s/n, Col. Palo de Santa Rita, Apd. 592, La Paz, B.C.S., \\ 23096, México \\ 2Instituto de Oceanología (IdO), 1ra, No. 18406, e/ 184 y 186, Rpto. Flores, Playa, C. Habana, 11600, Cuba \\ e-mail: atripp@ipn.mx
}

Capetillo-Piñar N., J. Espinosa Sáez, A. Tripp Valdez and A. Tripp Quezada. 2016. The Impact of Cyclonic Activity during 1981-1985 and 2004-2009 on Taxonomic Diversity of Mollusks in the Gulf of Batabanó, Cuba. Hidrobiológica 26 (1): 121-131.

\begin{abstract}
The cyclonic activity within the Gulf of Batabanó has been historically documented and, in the past two decades, it has been possible to observe signals of environmental degradation in its physical and biological state. Yet a study aimed at evaluating the effects of cyclonic activity on the taxonomic diversity of mollusks has not been made. The objective of this study was to evaluate the effects of cyclonic activity during 1981-1985 and 2004-2009 on the taxonomic diversity of soft-bottom mollusks of this region. To measure the cyclonic activity, the Power of Dissipation Index for hurricanes (PDI) was used. The average taxonomic distinctness index (Delta+) and the variation in the taxonomic distinctness (Lambda ${ }^{+}$of the inventory of the mollusks species for both periods were used as a measure of taxonomic diversity. We detected high cyclonic activity (HCA) during 2004-2009 and low cyclonic activity (LCA) during 1981-1985. The taxonomic composition during both periods was made up of 3 classes, 20 orders, 68 families, 155 genus, and 208 species. Significant differences in the taxonomic composition between the two periods were detected, due principally to the loss of genus and species. The taxonomic distinctness index reveals significant changes of the taxonomic structure of mollusks during 2004-2009, which is related to a rise in cyclonic activity. These results suggest that the taxonomic diversity of mollusks was less complex during 2004-2009 than during 1981-1985.
\end{abstract}

Key words: Gulf of Batabanó, hurricanes, mollusks, soft bottoms, taxonomic distinctness.

\section{RESUMEN}

La actividad ciclónica en el golfo de Batabanó ha sido históricamente documentada y en las últimas dos décadas ha permitido observar señales de deterioro ambiental en su medio físico y biológico. Sin embargo un estudio dirigido a evaluar Ios efectos de dicha actividad sobre las comunidades de moluscos de fondos blandos no se ha realizado. El objetivo de este trabajo fue evaluar los efectos de la actividad ciclónica registrada en los periodos de 1981-1985 y 2004-2009 sobre la diversidad taxonómica de la malacofauna de fondos blandos de esta región. Para medir la actividad ciclónica se utilizó el Índice de Disipación de Energía de los Huracanes (PDI). Los índices de distintividad taxonómica promedio (Delta ${ }^{+}$y la variación en la distintividad taxonómica (Lambda+) de los inventarios de especies de moluscos de ambos periodos fueron utilizados como medida de diversidad taxonómica. Se detectó una actividad ciclónica alta (AaC) para el periodo de 20042009 y baja (BaC) para el de 1981-1985. La composición taxonómica entre ambos períodos se conformó de tres clases, 20 órdenes, 68 familias, 155 géneros y 208 especies. Se detectaron diferencias significativas en la composición taxonómica entre ambos periodos, debido fundamentalmente a la perdida de géneros y especies. Los índices de distintividad taxonómica revelaron cambios significativos en la estructura taxonómica de los moluscos en el periodo 2004-2009 la que se relacionó con el aumento de la actividad ciclónica. Estos resultados indican que la diversidad taxonómica de los moluscos fue menos compleja en el período 2004-2009 que la del período 1981-1985.

Palabras claves: Distintividad taxonómica, fondos blandos, huracanes, Golfo de Batabanó, moluscos. 


\section{INTRODUCTION}

Hurricanes are natural phenomena that induce mortality, displacement, changes in the community structure of species (Boesch et al., 1976; Dauer, 1984; Knott \& Martore, 1971; Álvarez-Filip et al., 2009; Rodríguez \& Claro, 2009), and severe changes in the physical and chemical conditions of ecosystems (Lowery, 1992; Tilmant et al., 1994; Valiela et al., 1996; Hua et al., 2010).

Three hurricanes hit the Gulf of Batabanó during the first decade of this century. Hurricane Charley hit the region in August 2004, while Hurricanes Gustav and Ike struck in August and September of 2008, respectively. When they blew over the region, the strength of these three events measured 3, 4, and 2, respectively, on the Saffir Simpson hurricane scale.

Historically the Gulf of Batabanó has been affected by hurricanes, and researchers have begun to see signs of environmental degradation in several areas (Guerra et al., 2005; Cerdeira-Estrada et al., 2008). However, to date no study has determined the effects that these events have on mollusks of this region.

The Margalef and Shannon-Wiener species diversity indices and the Pielou evenness index (Shannon \& Weaver, 1949; Margalef, 1951; Pielou, 1966) have been the most utilized biological indicators for monitoring purposes and/or for detecting ecosystem changes (Magurran, 2004; Hong et al., 2010). This is because a reduction of species diversity to temporal or spatial scale is one of the main signs of a loss of biodiversity and habitats (Gaston \& Spicer, 2004). However, their usefulness as a good environmental indicator is greatly limited when sampling is not adequately controlled because these indices are highly dependent on effort and sample size as well as on the inherent characteristics of the habitat.

To eliminate this disadvantage, the Average Taxonomic Distinctness index (AVTD) (Warwick \& Clarke, 1995) and the Variation on the Taxonomic Distinctness index (VTD) (Clarke \& Warwick, 2001) were created. The AVTD is the average taxonomic distance between branches of the taxonomic tree to which all pairs of species recorded in a sample are connected. The AVTD can be interpreted as the average taxonomic width for the sample, while the VTD is the variance of taxonomic distances between each pair of species and is a reflection of how equitable the taxonomic tree of a community is. Both indices surpass traditional measures because they are independent of effort, sampling size, and habitat characteristics, and thus they can be used for comparisons between historical data of species communities with different sampling efforts and in different localities or regions (Clarke \& Warwick, 1998; Leonard et al., 2006).

Historically, the Gulf of Batabanó is subject to severe meteorological events and, given the evidence of environmental degradation in the area, our objective in this study was to evaluate the effects of cyclonic activity recorded during 1981-1985 and 2004-2009 on taxonomic diversity of the soft-bottom mollusks from this region, by using the AVTD and VTD indices.

\section{MATERIAL AND METHODS}

Study zone and databases. The Gulf of Batabanó (GB) is on the southwestern continental shell of Cuba ( $\mathrm{N} 21^{\circ} 25^{\prime}$ y $22^{\circ} 41^{\prime}$ and W $80^{\circ} 52^{\prime}$ y $\left.84^{\circ} 00^{\prime}\right)$, covering 21,305 square kilometers $\left(\mathrm{km}^{2}\right)$ with an average depth of $6 \mathrm{~m}$ (Cerdeira-Estrada et al. 2008). On the north and west coasts of the Isle of Youth and in the hundreds of cays that exists in the area, there are stretches of mangrove forests. The south portion is limited by cays, banks, and a continual reef crest interrupted by various inflow channels, which at times have good communication with the open sea (Fig. 1).

We use molluskinformationavailable from records of several varieties of benthonic soft bottoms habitats from GB. This study covered two environmental periods with different cyclonic activity: 1981-1985 and 20042009. For the 1981-1985 period, information was obtained from literature (Alcolado, 1990), comprising a species list with presence/absence data obtained at 20 sampling sites distributed throughout the GB (Fig. 1). The 2004-2009 period covers five years: 2004, 2005, 2007, 2008, and 2009. This data refer to a species list and the number of individuals recorded in each year. That information was obtained in 44 sampling sites distributed throughout the gulf.

In 2008, Hurricanes Gustav and lke hit the gulf. Mollusk samples were taken 15 days before the passage of Hurricane Gustav (August 2008) and 25 days before the arrival of Hurricane lke (September 2008). After the passage of these two hurricanes, we took samples at 36 days (October 2008), seven months (April 2009), and one year (August 2009).

We obtained this information from the databases of Cuba's Institute of Oceanology and Fisheries Research Center. The periods analyzed cover a total of 29 years.

The scientific names of the recorded species in each period were standardized according to current taxonomic nomenclature, using nomenclature checklists (Espinosa y Ortea, 1998, 2001, 2003, 2010; Ortea \& Espinosa, 2001; Mikkelsen \& Bieler, 2008; Rosenberg et al., 2009; Turgeon et al., 2009). The taxonomic ordination was also updated (Bouchet et al. (2005) and Espinosa et al. (2005)).

Taxonomic diversity measure and cyclonic activity. We calculated the average taxonomic distinctness index and the variation in the taxonomic distinctness of the samples by using equations proposed by Warwick \& Clarke (1995) and Clarke \& Warwick $(1998,2001)$.

1. Average Taxonomic Distinctness Index (Delta $\left.{ }^{+}\right)$

$$
\Delta^{+}=\left[\sum \sum_{\mathrm{i}<\mathrm{j}} \mathrm{w}_{\mathrm{ij}}\right] /[\mathrm{S}(\mathrm{S}-1) / 2]
$$

2. ariation in the taxonomic distinctness (Lambda $\left.{ }^{+}\right)$

$$
\Delta^{+}=\left[\sum \sum_{\mathrm{i}<\mathrm{j}}\left(\mathrm{w}_{\mathrm{ij}}-\Delta^{+}\right)^{2}\right] /[\mathrm{S}(\mathrm{S}-1) / 2],
$$

where $w_{i j}$ is the distinctness weight given to the path length linking species $i$ and $j$ in the hierarchical taxonomic tree and $S$ is the number of species (Clarke \& Warwick, 1998).

Cyclonic Activity. The annual cyclonic activity that affected the GB in the two study periods was estimated by the Power Dissipation Index (PDI) using the equation $\mathrm{PDI}=\sum \mathrm{V}^{3}$ (Emanuel, 2005), where $\mathrm{V}$ is the maximum sustained wind speed, measured every 6 hours while the hurricanes were in the area (http:// weather.unisys.com/hurricane/atlantic/ index.php).

Taxonomic composition. We analyzed the observed taxonomic composition of each period of study to the levels of class, order, family, genus, and species, using a variance analysis (ANOVA), by comparing the species lists to detect the existence of differences between the two periods. 


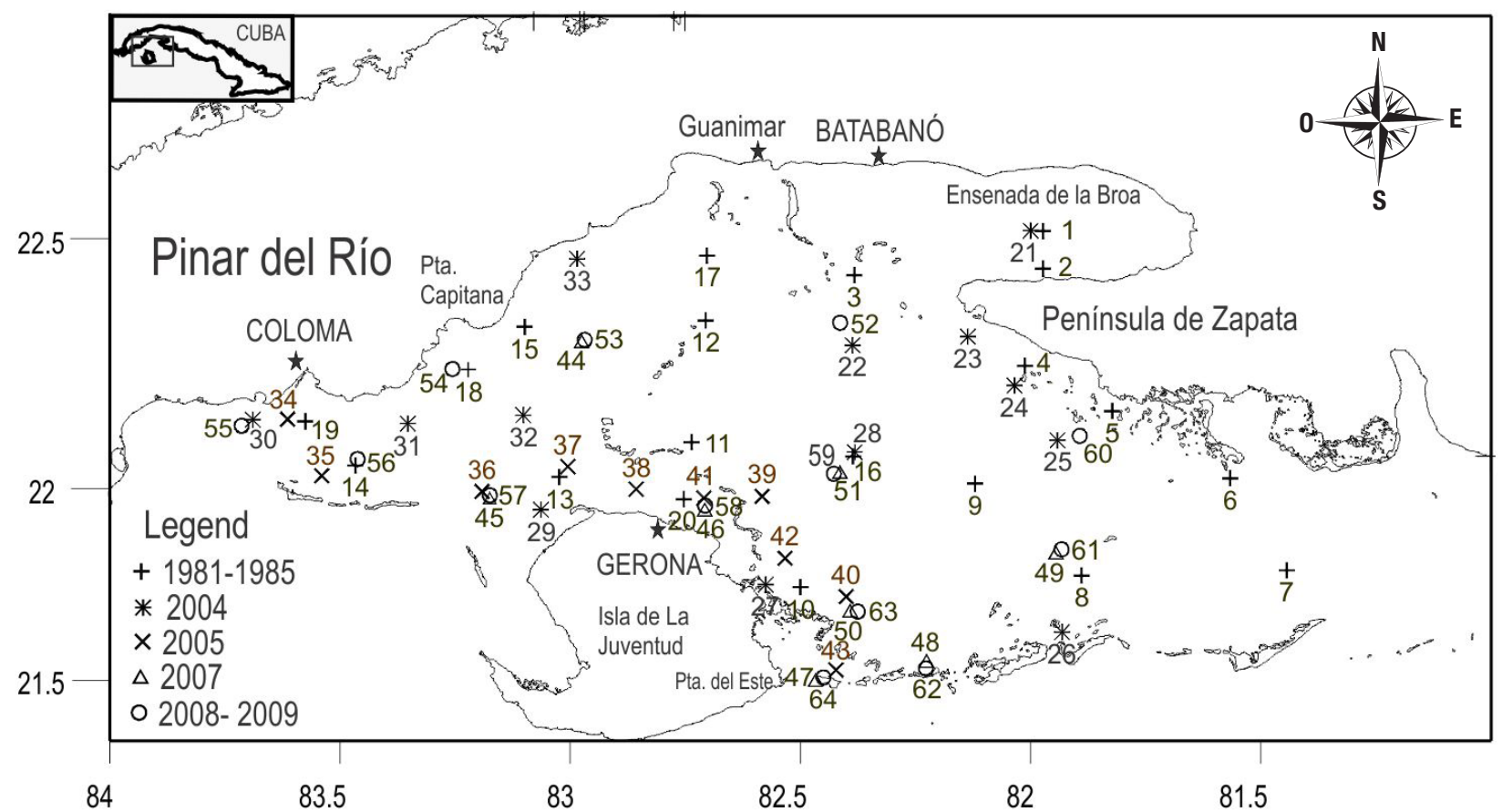

Figure 1. Sampling sites of the soft-bottom mollusks of the Gulf of Batabanó for two periods of cyclonic activity: 1981-1985 (Low cyclonic activity: LCA) and 20042009 (High cyclonic activity: HCA).

Delta $^{+}$and Lambda ${ }^{+}$calculation. To simulate Delta ${ }^{+}$and Lambda ${ }^{+}$ a hierarchical Linnaean classification of five taxonomic levels (class, order, family, genus, and species), was used as a proxy for cladograms representing the relatedness among species and a presence/absence data matrix was made.

For this study, the taxonomic weights used were those proposed by Clarke \& Warwick (1998) in the context of mollusk classes: $W=1$ (species in the same genus), 2 (different genus in one family), 3 (different families in one order), and 4 (different orders in one class). The distinctness of two species linked to the higher level was fixed at a value of 100 (Clarke \& Warwick, 1998; Warwick \& Clarke, 2001). We obtained the values of Delta ${ }^{+}$y Lambda ${ }^{+}$by using the DIVERSE routine of the PRIMER-E v6 software (Clarke \& Gorley, 2006).

Delta $^{+}$and Lambda ${ }^{+}$simulation test. Using a randomized method without replacement, we derived the expected values of Delta ${ }^{+}$and Lambda $^{+}$from the master species list. Once the number of species is plotted, the list gives a tunnel-shaped distribution in which the confidence intervals are at $95 \%$ (Clarke \& Warwick, 1998). With this method, we made a bivariate representation of the values of Delta ${ }^{+}$and Lamb$\mathrm{da}^{+}$from the expected values of both indices, whose distributions were represented in the shape of ellipses with confidence levels of $95 \%$ for a range of sub-lists of species of different sizes (Warwick \& Clarke, 2001). Through these two simulated distributions, it is possible to measure the magnitude of the deviations between the observed and the expected values for both indices. We made these analyses using the TAXTES routine of PRIMER-E (Clarke \& Gorley, 2006).

Impact of cyclonic activity on taxonomic diversity. This analysis was performed in two ways: 1- graphically comparing the standardized anomalies of taxonomic indices (Delta ${ }^{+}$and Lambda ${ }^{+}$) with cyclonic activity (PDI) in each year and/or period; and 2- comparing the observed variation in the values of taxonomic indexes before and after the passage of hurricanes in the gulf. The latter was performed using a comparative table.

Community structure. The temporal variation of the mollusk community structure at GB was analyzed using a multivariate ordination test (MDS), and the Sorensen index to compute the similarity matrix. The ANOSIM test checked for the existence of significant differences between groups formed by the ordination. The two analyses were run using the PRIMER-E software (Clarke \& Gorley, 2006).

\section{RESULTS}

Cyclonic activity. Cyclonic activity during 1981-1985 was lower (LCA) than during 2004-2009 (HCA). In the latter period, 2004 and 2008 experienced the most cyclonic activity, given that hurricane Charley in 2004 and hurricanes Gustav and Ike in 2008 directly hit the GB. There was no cyclonic activity in 2005, 2007, and 2009 (Fig. 2).

Taxonomic Composition. The taxonomic composition of the softbottom mollusks of the GB was 208 species in 155 genus, 68 families, 20 orders, and 3 classes.

The most remarkable differences found in these categories were at the families, genus, and species levels, being most significant ( $\mathrm{F}=$ 24.36, $p=0.041$ ) for the LCA period with respect to the HCA (Fig. 3).

Temporal and spatial variation of the taxonomic distinctness indices. The expected results from delta ${ }^{+}$and lambda ${ }^{+}$indices for the 29 years of this study were 87.20 and 240 respectively. In Table 1 the observed values of the delta+ and lambda+ indices are shown for each period. 


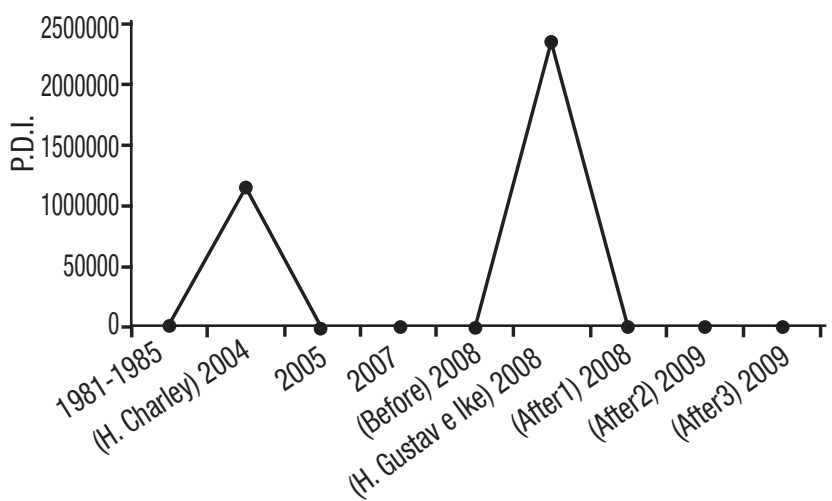

Figure 2. Annual variation of the Power Dissipation Index (PDI) of the hurricanes that affected the Golfo de Batabanó in the 1985-1981 and 2004-2009 periods.

The lowest value of delta $(81.60)$ and the higher value of lambda ${ }^{+}$ (346.20) corresponded to 2008 of the HCA period, while for the remaining years of this period the delta ${ }^{+}$values varied between $86.21-86.88$ and the lambda+ values between the $255.95-279.93$. The average values for delta ${ }^{+}$and lambda+ for this period were 85.46 and 285.67 respectively (Table 1).

Figure 4 represents the probabilistic funnels for the simulated values of delta ${ }^{+}$and lambda ${ }^{+}$with its probabilistic contours at $95 \%$. In this figure, we observe an evident separation of the LCA with respect to the HCA. In this last period, the values of delta ${ }^{+}(81.60)$ and lambda ${ }^{+}$ (346.20) for 2008 and lambda ${ }^{+}$(290.54) for 2009 were located out of the probabilistic contour of their respective funnels (Fig. $4 \mathrm{a}$ and b respectively). The values of both indices for the remaining years $(2004,2005$, and 2007) of the HCA and LCA periods fell inside the probabilistic contours. For 2009, delta+ fell within the contours of the probabilistic funnel.

The spatial analysis of taxonomic diversity patterns of mollusks assemblages at GB showed that all sampling sites during the LCA period (1981-1985) were located within the limits of probabilistic funnels for both indices (Fig. 4c and d) . However, 37\% of the sampling sites in the HCA period (2004-2009) were outliers, either below or above the limits of probabilistic funnels for both indices (Fig.4c and d). Most sampling sites that fell outside the contours of probabilistic funnels of delta $^{+}$and lambda ${ }^{+}$belonged to 2004, 2008, and 2009.

The lowest values of delta ${ }^{+}$were recorded at sites 24,27 , and 33 (2004) and 54, and 55 for 2008. Hurricanes were reported in both years. Regarding lambda ${ }^{+}$sites, 33 and 24 had the lowest values, while site 54 had the highest value (Fig. $5 \mathrm{a}$ and $\mathrm{b}$ ).

For 2005, sampling site 34 fell outside the lower limit of the probability funnel for delta ${ }^{+}$(Fig. 5a). For 2007, site 48 was located outside and above the limit of the probability funnel for lambda+ (Fig. 5b).

Relation of delta ${ }^{+}$ lambda ${ }^{+}$indices with cyclonic activity. Delta ${ }^{+}$ showed positive anomalies associated with negative anomalies for lambda+ in 1981-1985 and in 2004, 2005, and 2007 (Fig. 6). Except for 2004, during 1981-1985 and the remaining years (2005 and 2007), there was no cyclonic activity. In 2008, however, this pattern was reversed. Delta ${ }^{+}$and lambda ${ }^{+}$showed positive anomalies before the impact of Hurricanes Gustav and Ike (2008B), and once they affected the region

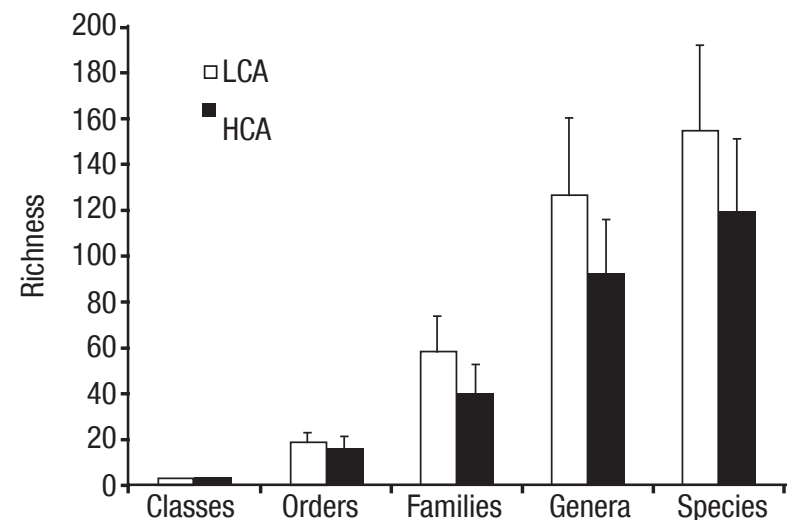

Figure 3. Number of classes, orders, families, genera, and species of the soft bottoms mollusks of the Gulf of Batabanó, for each period under study.

Table 1. Delta+ and Lambda+ index values of the soft bottom mollusks of the Gulf of Batabanó in the periods of low cyclonic activity (LCA) and high cyclonic activity (HCA).

\begin{tabular}{cccc}
\hline Cyclonic activity & Period/Years & Delta $^{+}$ & Lambda $^{+}$ \\
\hline LCA & $1981-1985$ & 86.96 & 234.24 \\
HCA & $2004-2009$ & & \\
& 2004 & 86.21 & 271.42 \\
& 2005 & 86.88 & 255.95 \\
2007 & 86.40 & 279.93 \\
& 2008 & 81.60 & 346.20 \\
& 2009 & 86.25 & 274.89 \\
& Mn & $85.4 \mathrm{ea} 6$ & 285.67 \\
\hline
\end{tabular}

(33 days of hurricane passage (2008A1), delta ${ }^{+}$posted the lowest negative anomaly $(-2.4)$ and lambda + the highest positive anomaly $(+1.91)$ for the entire period (Fig. 6).

In 2009, a change was observed in the response pattern of these indices to cyclonic activity. Positive anomalies occurred in delta ${ }^{+}$and lambda+ seven months after the hurricanes had passed, reestablishing the original pattern (positive anomalies of delta ${ }^{+}$and negative anomalies lambda+), a year after the hurricanes passed. (Fig. 6).

A Pearson correlation analysis of the PDI, delta ${ }^{+}$, and lambda ${ }^{+}$indices reveals a very high correlation between the two indices and cyclonic activity (delta ${ }^{+}: r=-0.72, p=0.042$ y lambda ${ }^{+}: r=0.83, p=0.031$ ). This correlation showed that the lowest delta ${ }^{+}$and highest lambda ${ }^{+}$ values were due to high cyclonic activity. (Fig. 6)

Delta $^{+}$and lambda ${ }^{+}$showed significant changes in their values between, before, and after the passage of hurricanes (Table 2). The value of delta ${ }^{+}$decreased in 0ctober 2008 (36 days after the passage of hurricanes), increased in April 2009 (seven months after the passage of hurricanes), and August 2009 (one year after the hurricanes). Lambda ${ }^{+}$ increased its value in October 2008, decreasing in April and August 2009 (Table 2). 

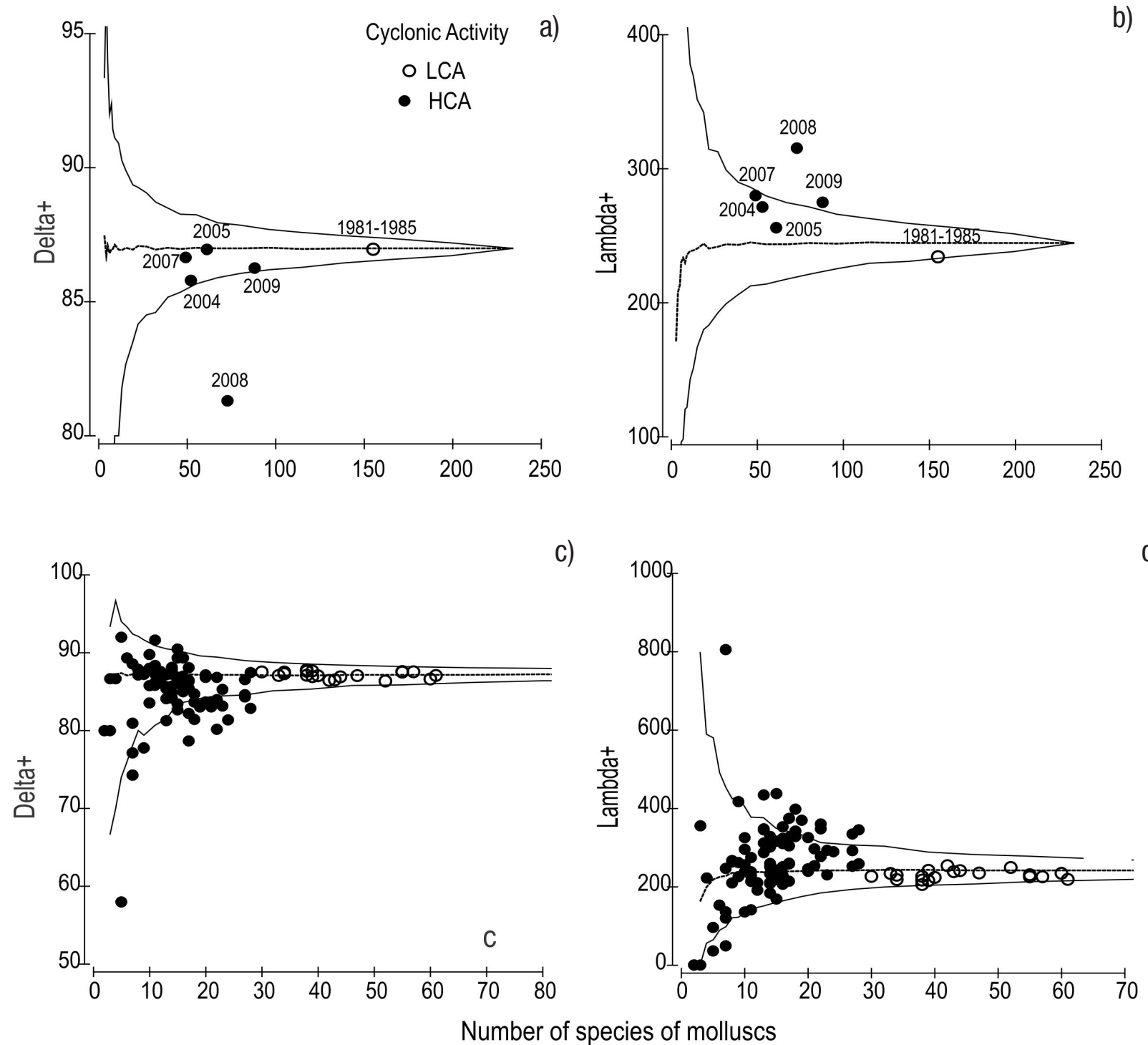

Figures 4a-d. Relation between values of the average taxonomic distinctness index (Delta+) and variations of taxonomic distinctness (Lambda ${ }^{+}$) in mollusk species richness in the Gulf of Batabanó, calculated for the LCA and HCA periods. The mean (thick line) and the contour of confidence of 95\% (thin line) were obtained by a randomized process (999 iterations) of the subsamples of the number of species of a master list throughout the period. a and b: temporal analysis and $\mathrm{c}$ and d: spatial analysis.

Mollusk community structure. The MDS test of temporal and spatial scale shows two clearly separated groups with significant differences (ANOSIM $_{\text {temporal }} R=1, p=0.01$ and ANOSIM ${ }_{\text {spatial }} R=0.424, p=0.01$ ), which corresponded to each of the periods analyzed (Fig. 7a y b). In the group that belongs to the HCA, we observed a certain dispersion of the sampled years, with 2005 being the most isolated and 2008 and 2009 the closest (Fig. 7a). This situation was similar to the spatial scale where sites sampled during the HCA period were observed with some dispersion with respect to the LAC (Fig. 7b).

The MDS test before and after the passage of hurricanes in 2008 showed a clear separation between sites sampled before (B) and 36

Table 2. Average values of Delta ${ }^{+}$and Lambda+ mollusks in the Gulf of Batabanó measured before and after the passage of Hurricanes Gustav and Ike in 2008.

\begin{tabular}{ccccccc}
\hline Indices & 2008B & $2008 \mathrm{~A} 1$ & $2009 \mathrm{~A} 2$ & $2009 \mathrm{~A} 3$ & $\mathrm{~K}-\mathrm{W}$ & $p$ \\
\hline Delta $^{+}$ & $86.7 \pm 0.9$ & $68.5 \pm 4.8$ & $83.9 \pm 3.2$ & $84.6 \pm 2.2$ & 8.64 & $\mathbf{0 . 0 4 0}$ \\
Lambda $^{+}$ & $299.6 \pm 23.2$ & $368.2 \pm 16.41$ & $319.7 \pm 93.9$ & $285.7 \pm 64.2$ & 9.83 & $\mathbf{0 . 0 3 1}$ \\
\hline
\end{tabular}

Note: 2008B: August 2008 (before p/h), 2008A1: 0ctober 2008 (36 days after p/h), 2009A2: April 2009 (seven months after p/h), 2009 A3: August 2009 (one year after $\mathrm{p} / \mathrm{h}), \mathrm{p} / \mathrm{h}$ : passage of hurricanes, K-W: Non parametric ANOVA Kruskal Wallis. 


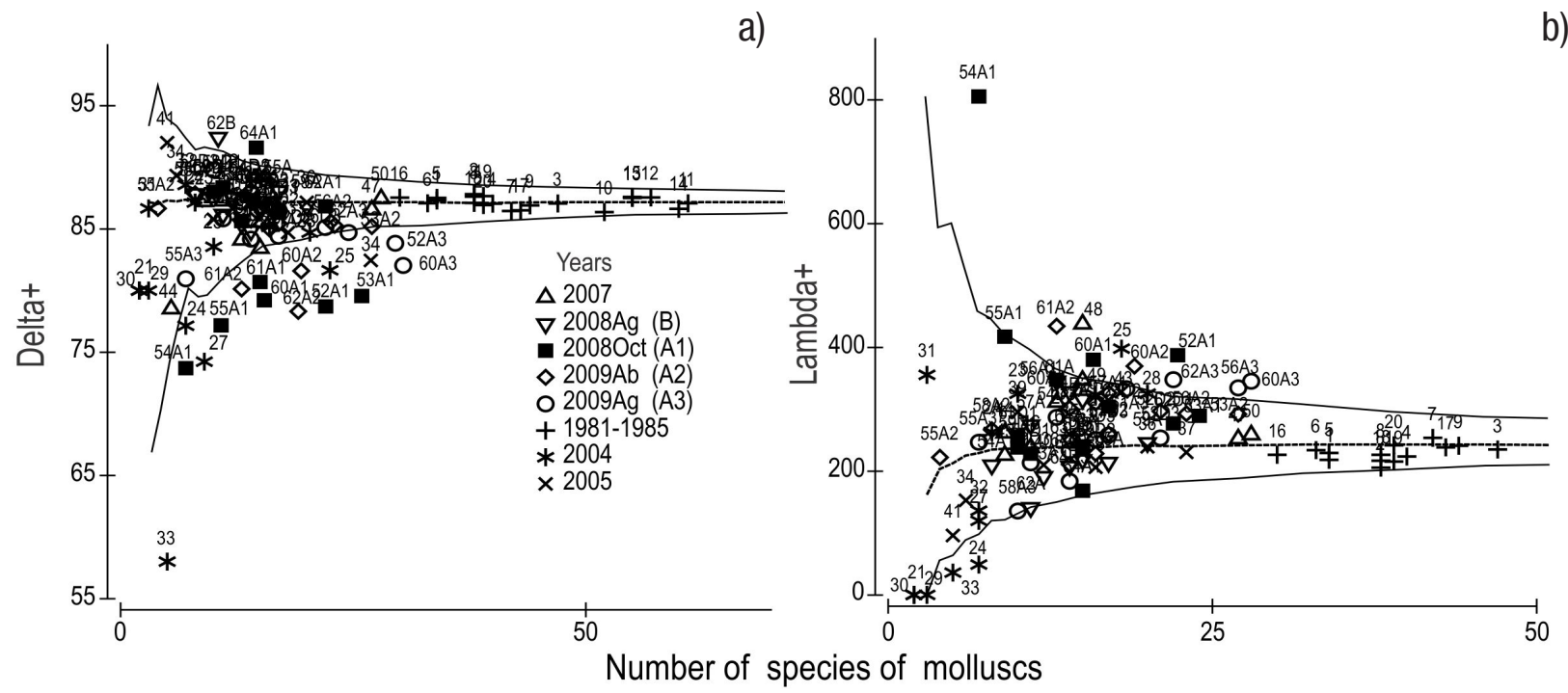

Figures 5a-b. Relation of the values of the average taxonomic distinctness index (a) and the variation of the taxonomic distinctness (b) with mollusk species richness in the Gulf of Batabanó before (B) and After (A1: 36 days, A2 (seven months) and A3 (one year) after of passage of hurricanes Gustav and lke in 2008. The mean (thick line) and the contour of confidence of $95 \%$ (thin line) were obtained by a randomized process (999 iterations) of the subsamples of the number of species of a master list throughout the period.

days after the passage of hurricanes (A1). Seven months (A2) and one year (A3) after hurricanes had passed, a good separation of sampling sites was not observed (Fig 7c). Applying the ANOSIM test before and after the passage of hurricanes showed significant differences in mollusk community structure (Table 3).

\section{DISCUSSION}

The decrease in variety of orders, families, genus, and species in the HCA period (Fig. 3) is a result of the increase in cyclonic activity in the $\mathrm{GB}$, characterized by the increase in the frequency and intensity of the hurricanes (Fig. 2). Puga et al. (2013) and Alzugaray (2015) have also documented this trend in the entire Caribbean region over the past 30 years (IPCC, 2007).

Cyclonic activity (PDI) is controlled by inter-annual variability, decadal, and multi-decadal processes (for example, ENSO events (Chu,
2004), and multi-decadal Atlantic 0scillation (AM0) (Vimont \& Kossin, 2007)). The fact that cyclonic activity was observed in 2004 and 2008, but not in 2005, 2007, and 2009, can be justified by the dynamics of these processes.

Significant changes in mollusk taxonomic structure were detected through the delta ${ }^{+}$and lambda ${ }^{+}$indices and through probabilistic funnels before and after the passage of hurricanes (Fig. 5).

The probabilistic funnels of the two indices indicated a clear separation between the mollusk taxonomic patterns in both periods. These patterns were significant due to the observed variations in the HCA period. This period was affected by three hurricanes with different frequencies and intensities, causing the variations in the values of del$\mathrm{ta}^{+}$and lambda (Table 2) and in mollusk taxonomic patterns (Fig. 2). Mollusk taxonomic patterns in 2004, 2005, 2007, and 2009A3, were similar to those of the LCA period. In 2005, 2007, and 2009A3, this was

Table 3. ANOSIM test results between before and after the passage of Hurricanes Gustav and Ike in the Gulf of Batabanó. Analyses were based on the similarity coefficient of Bray -Curtis. $(\mathrm{R}$ (global) $=0.195, \mathrm{p}=0.1 \%)$.

\begin{tabular}{|c|c|c|c|c|c|}
\hline \multirow{3}{*}{ Groups } & \multirow{3}{*}{$\begin{array}{c}\text { Statístic } \\
\text { R }\end{array}$} & \multirow{3}{*}{$\begin{array}{l}\text { Significance } \\
\text { Level } \\
(\%)\end{array}$} & \multirow{2}{*}{\multicolumn{2}{|c|}{ Permutations }} & \multirow{3}{*}{$\begin{array}{l}\text { No.>= } \\
\text { Observec }\end{array}$} \\
\hline & & & & & \\
\hline & & & Possible & Actual & \\
\hline Before, After1 & 0.397 & 0.1 & 5200300 & 999 & 0 \\
\hline Before, After2 & 0.227 & 0.1 & 5200300 & 999 & 0 \\
\hline Before, After3 & 0.228 & 0.1 & 5200300 & 999 & 0 \\
\hline After1, After2 & 0.254 & 0.1 & 5200312 & 999 & 0 \\
\hline After1, After3 & 0.103 & 1.8 & 5600200 & 999 & 17 \\
\hline After2, After3 & -0.001 & 44.3 & 5400210 & 999 & 442 \\
\hline
\end{tabular}




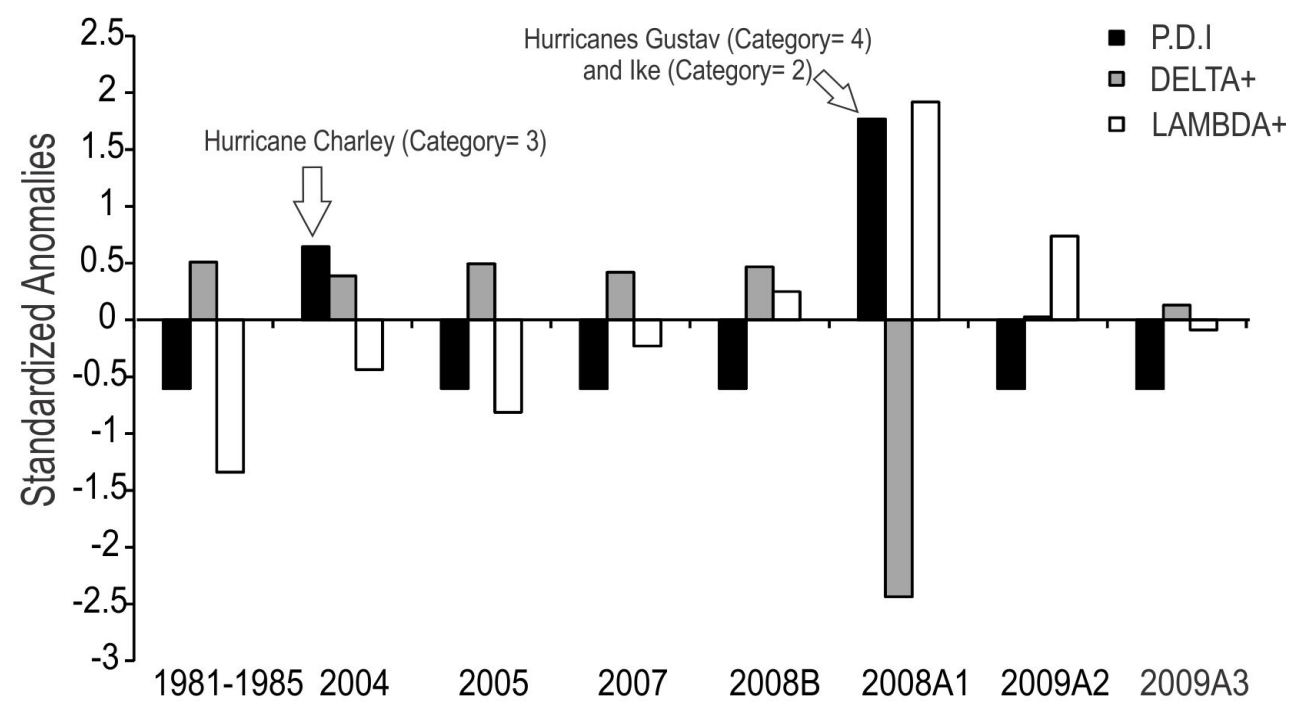

Figure 6. Standardized anomalies Delta+ and Lambda+ mollusks in the Gulf of Batabanó with cyclonic activity (PDI). Before (B) and after (A1: 36 days, A2: seven months and A3: one year) of passage of hurricanes Gustav and lke.

due to the absence of cyclonic activity. In 2004, when Hurricane Charley struck, this result was due to the delay in sampling after the hurricane passed, some three months after the event. It is possible that by the time samples were taken, mollusk assemblages had recovered from the effects of the hurricane.

Taxonomic patterns for 2009A2 and 2008B (Table 2, Fig. 2) were due to environmental conditions that prevailed before and seven months after Hurricanes Gustav and Ike. These conditions might include the differences and/or similarities in temperature $\left(2008 \mathrm{~B}: 31.7^{\circ} \mathrm{C}\right.$ vs $2009 \mathrm{~A} 2: 27.4^{\circ} \mathrm{C}$ ), salinity (2008B : $38.73 \%$ vs $2009 \mathrm{~A} 2: 38.23 \%$ ), and turbidity (2008B : 1.23 FTU vs 2009A2 : $2.41 \mathrm{FTU}$ ) recorded before and seven months after the hurricanes (Capetillo et al., 2011). These variables of turbidity had significant changes before and after the hurricanes, as well as the spatial scale, whose recovery occurred about one year after the hurricanes in some zones of GB (Capetillo et al., 2011). This situation may have affected seagrass beds in the region.

In 2008A1, the taxonomic pattern was very different from those observed previously (Table 2, Fig. 2). This was due to two causes: 1 - the sum of the effects caused by Hurricanes Gustav and Ike, spaced just 11 days apart; and 2- the samples taken just 36 days after their passage in GB. This gives tests to detect the effects caused by hurricanes influences, besides the intensity and frequency of these, time in sampling after the passage of these natural events.

During the LCA period, the values from delta ${ }^{+}$and lambda ${ }^{+}$fell inside the contours of probabilistic funnels (Fig. 4a and b) showing that the mollusk taxonomic pattern in this period did not change over the 29 years covered by both periods. The closeness of the delta ${ }^{+}$value (86.96) and lambda+ value (234.2) to their expected values, i.e., (87.20) and (240), respectively, demonstrates the high stability of the mollusk communities' taxonomic pattern during this period. This was due to the low cyclonic activity that prevailed in this period (Fig. 2), although we could not dismiss the incidence of other environmental variables. An- thropogenic activity in the region in those years was low. In this regard, several authors have suggested that the 1980s were characterized by low cyclonic activity, and anthropogenic effects did not cause any significant changes in ecosystem quality in the GB, due to low human activity in this period (Puga et al., 2013).

The lowest significant value of delta ${ }^{+}(81.60 ; p<0.05)$ and the highest significant value of lambda ${ }^{+}(346.20 ; p<0.05)$ in 2008 indicate that the mollusk taxonomic tree (taxonomic structure) was the most separated (least complex) and least balanced (less equitable) of all trees compared in the remaining years $(2005,2007,2009)$ of the HCA and the LCA. This situation was due to the loss of some taxonomic categories and to the existence of a very irregular distribution of species on the taxonomic tree that occurred after the hurricanes struck. A detailed analysis of mollusk taxonomic composition during both periods indicated that the Class Gasteropoda was the most affected during HCA, due to the loss of 20 genera (LCA 62 vs HCA 42) and 28 species (LCA:81 vs HCA:53) compared to the LCA period. However, since this period was characterized by an increase in human activity (Puga et al., 2013), which was confined in areas located in or near the coast of the northern of GB (Périgo et al., 2005; Alonso-Hernández et al., 2011), changes observed in gastropods cannot be attributed solely to hurricanes.

The effects caused by these natural events and by human activity (or the combination of these) can be identified by using these indices (Fig. 5a).

Except for site 27, the lower values of delta ${ }^{+}$were located in the northern gulf coast (sites 24, 33, 54, 55), (Fig. 5a). In this region and neighboring areas, contamination by organic matter (sites 33 and 55 ) and heavy metals (site 54) have been recorded (Périgo et al., 2005; Alonso-Hernández et al., 2011). At these sites researchers have observed muddy or sandy mud bottoms with little coverage or absence of seagrass (Arias-Schreiber et al., 2008; Cerdeira-Estrada et al., 2008). This situation could have intensified with the passage of hurricanes, 
Passage/Hurricanes

$\nabla$ BEFORE

A1(36 days)

$\diamond$ A2 (7 months)

$\mathrm{O}$ A3 (1 year)
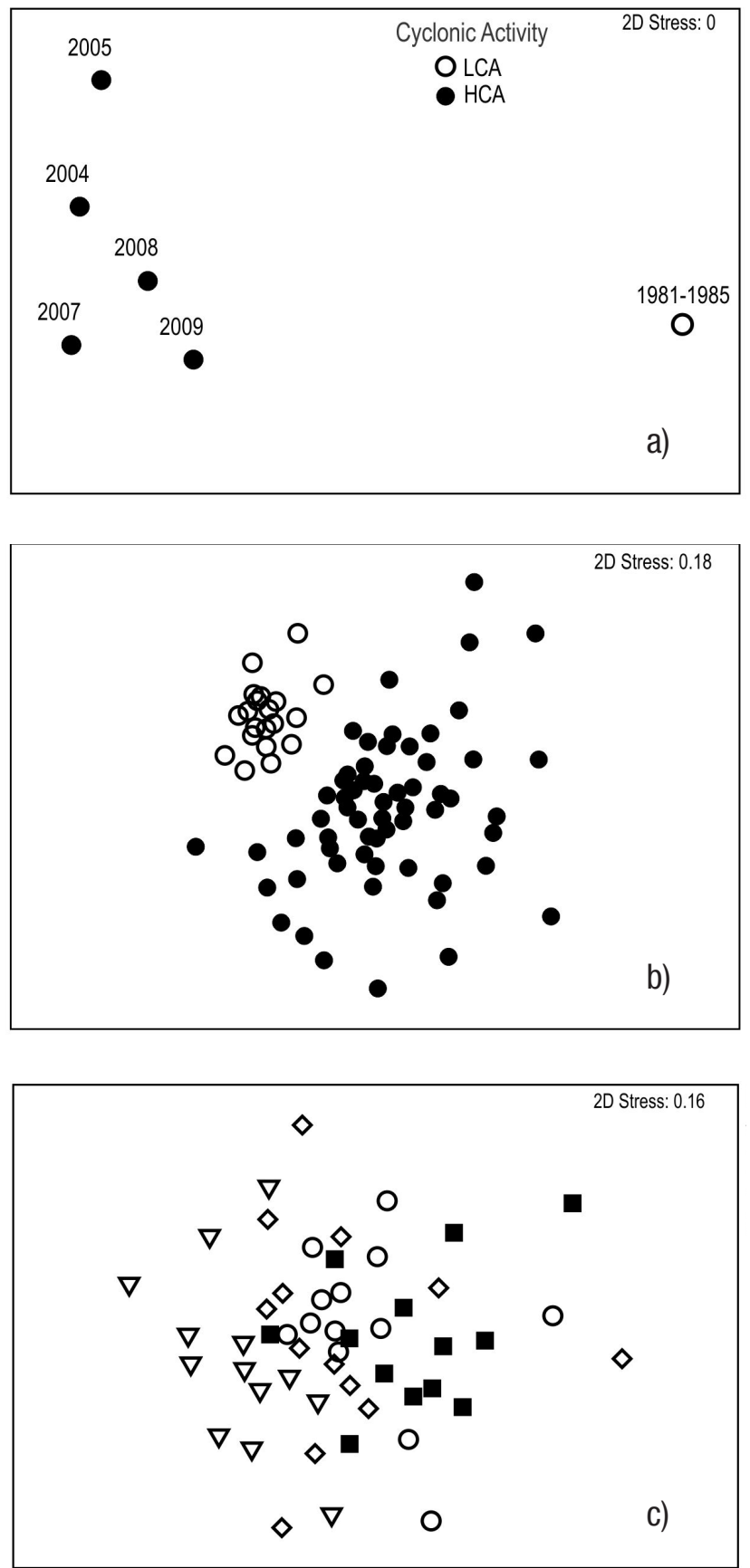

Figures 7a-c. Non metric Multi Dimensional scaling (MDS) of periods of LCA and HCA for the analysis of the community structure of molluscs soft bottom of the Golfo de Batanó. a) Temporal scale. b) Spatial scale. c) Before and after the passage of hurricanes Gustav and Ike in the year 2008. A1, A2 an A3, refer to the samples taken after the passage of the hurricanes. given the increased land-to-gulf transport of sediment and pollutants. This demonstrates that the low values recorded in those sites could be due to the combined effect of hurricanes with anthropic activity.

The changes in the mollusk taxonomic structure in sites 24 and 33 were similar to the results reported by Arias-Schreiber et al. (2008) and Hidalgo \& Areces (2009). They found significant differences in community structure, biomass, and densities in the macrozoobenthos when compared to the results obtained by Alcolado (1990) and Ibarzábal (1990).

Sites 52, 53, 60, 61, and 64, had higher delta+ values and were located in remote areas of the north gulf coast. At these sites, however, mollusk taxonomic structure was affected because the trajectories of Gustav and Ike passed directly or close to them (Fig 8b). This showed that only hurricanes had an impact.

The low value of delta ${ }^{+}$at site 34 (in 2005), the high value of lamb$\mathrm{da}^{+}$at site 48 (2007), and high value of delta ${ }^{+}$at site $61 \mathrm{~B}$ (2008B) can be explained by environmental conditions prevailing in those years. Further, high temperatures $\left(27.7^{\circ} \mathrm{C}-31.7^{\circ} \mathrm{C}\right)$ and salinities $(38.2 \%$ - 38.7\%) were recorded in those years (Capetillo et al., 2011). Hoskins (1964), Martinez - Estalella \& Alcolado (1990), and Espinosa (1992) stated that salinity, presence of vegetation, among other factors, can control mollusk distribution.

Several authors, in addition to testing the usefulness of delta ${ }^{+}$and lambda+ to measure human impact, proved that delta+ was an effective index to detect the impacts of natural disturbances, by recording changes in salinity at estuaries and coastal lagoons, and showed that lambda ${ }^{+}$is a better indicator of eutrophication (Warwick \& Clarke, 1995; Clarke \& Warwick, 2001; Mouillot et al. (2005). This suggests that these indices are capable of detecting the effects induced by natural events, a point demonstrated with this study.

The high negative correlation of delta ${ }^{+}(r=-0.72)$ and positive correlation of lambda+ $(r=0.83)$, both of which are significant, with the PDI (Fig. 6a and b), as well as their sensitivity in detecting the effects of hurricanes (Table 2), demonstrate that both can detect the effects caused by hurricanes due to the clear trend in the temporal and spatial variation of the width (delta ${ }^{+}$) and balance (lambda+) of the soft-bottom mollusk taxonomic tree in the region. The taxonomic structure becomes narrower and less balanced in the 2004 and 2008, being both properties (width and balance) of the taxonomic tree that were significant in 2008 but not in 2004 (Fig. 4a and b). During 2009, the value of lambda ${ }^{+}$ was higher and more significant than 2004 (Fig. 4b), which showed low evenness in the distribution of species in the taxonomic tree.

However, the fact that no hurricane hit this region that year seems to indicate that the situation found in 2009 could be due to the effect caused by the hurricanes in 2008 .

The MDS tests regarding the temporal and spatial scale of the mollusk community structure demonstrated the existence of two different structures in each of the scales analyzed. One of the structures was made up of the mollusks communities in the LCA period and the other in the HCA (Fig. 7a and b). The separation observed between the sampled years in the HCA period could be due to the different inter-annual environmental conditions, characterized by the hurricanes of 2004 and 

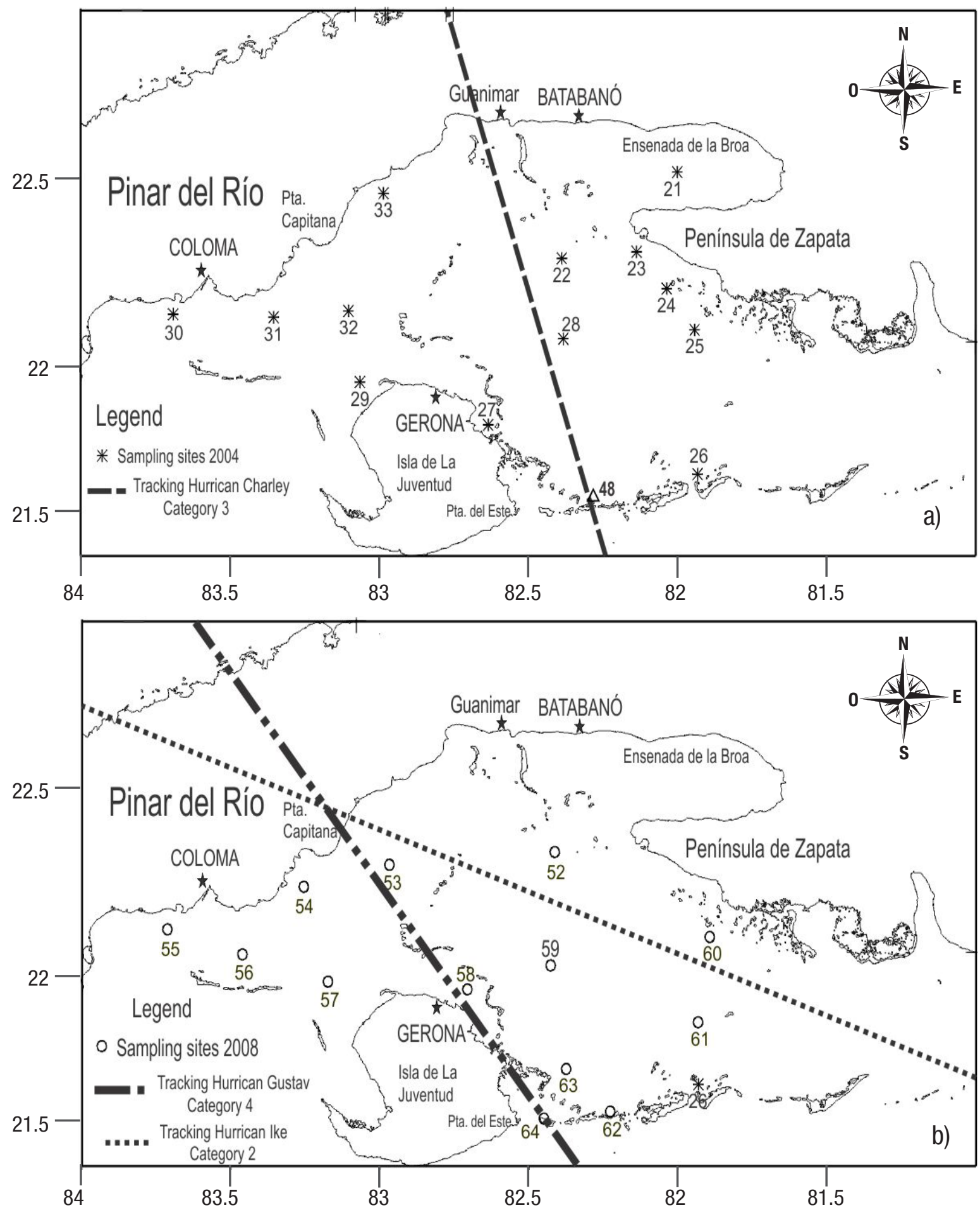

Figures 8a-b. Map of the path of hurricanes Charley (a), Gustav and lke (b) in the Gulf of Batabanó.

2008. This was not the case in 2005,2007 , and 2009. The spatial scale differences, however, may be due to: 1. the spatial difference in the effects of human activity in the gulf; and, 2- the severity of the hurricanes at each particular site, according to its trajectory.
The existence of significantly different mollusk community structures before and after the passage of hurricanes Gustav and Ike in 2008 (Fig. 7c) confirmed previous observations, as do the results obtained by delta $^{+}$and lambda ${ }^{+}$. 
A question we find interesting is why differences exist in the community structure and taxonomic patterns in the years when the effects of hurricanes were felt, when supposedly their effects on mollusk communities should have been the same. However, this result suggests the existence of a temporal variation in the community structure of these organisms, confirming the taxonomic patterns detected by the delta ${ }^{+}$ and lambda+ indices described in this study.

Hurricanes cause changes in reef biota, mangroves, sea grasses, and the sedimentary dynamics, while the frequency of occurrence, intensity, and duration of these events on a particular zone will determine if the affected ecosystems can recover (Salazar-Vallejo, 2002). From this statement, we can hypothesize that one of the elements that affect the difference of the effects in mollusk community and taxonomic structure during 2004 and 2008 was the frequency and intensity of the hurricanes during the HCA period. In order to confirm this statement, future studies should be made after hurricanes strike the GB with different intensities and duration.

In synthesis, the effect caused by cyclonic activity on the taxonomic diversity of the soft-bottom mollusks of GB was to reduce complexity and evenness of the taxonomic structure of these organisms. Given this condition, mollusks species were more closely related in the period of HCA, compared to the LCA. The loss of complexity in the taxonomic structure was due to: 1. the reduction of higher taxonomic categories; and 2. low evenness of species in these taxonomic categories.

\section{ACKNOWLEDGEMENTS}

The authors thank the support received by the Project SIP-IPN (20150821). As well as the Instituto Politécnico Nacional de México through the programs, COFFA and BEIFI. We thank CONACyT de México for the support granted with a Doctorate scholarship. Special gratitude to the Centro de Investigaciones Pesqueras and the Instituto de 0ceanología de Cuba for the assistance provide

\section{REFERENCES}

AlCOLADO, P. M.1990. El Bentos de la Macrolaguna del Golfo de Batabanó. Editorial Academia, La Habana, 161p., 75 figs, 50 tablas.

Alonso-Hernández, C. M., F. Conte, C. Misic, M. Barsanti, M. Gómez-Batista, M. Díaz-Asencio, A. Covazzi-Harriague \& F. G. Pannacciulli. 2011. An overview of the Gulf of Batabanó (Cuba): Environmental features as revealed by surface sediment characterization. Continental Shelf Research 31: 749-757.

Álvarez-Filip, L., M. Millet-Encalada \& H. Reyes-Bonilla. 2009. Impact of Hurricanes Emily and Wilma on the coral community of Cozumel Island, México. Bulletin of Marine Sciences 84 (3): 295-306.

Alzugaray, R. M. 2015. Efecto de los ciclones tropicales sobre el reclutamiento de la langosta Panulirus argus (Latreille, 1804) en el Golfo de Batabanó, Cuba. Tesis presentada en opción al título académico Master en Biología Marina y Acuicultura con Mención en Biología Marina. Centro de Investigaciones Marinas, UH, Cuba, 64 p.

Arias-Schreiber, M., M. Wolf, M. Cano, B. Martínez-Daranas, Z. Marcos, G. Hidalgo, S. Castellanos, R. del Valle, M. Abreu, J.C. Martínez, J. Díaz \& A.
ARECES. 2008. Changes in benthic assemblages of the Gulf of Batabanó (Cuba) - results from cruises undertaken during 1981-85 and 2003-04. Pan-American Journal of Aquatic Sciences 3(1): 49-60.

Bouchet, P., J. Freda, B. Hausdorf, W. Ponder, A. Váldes \& A. Warén. 2005. Working Classification of the Gastropoda. En Classification and Nomenclator of Gastropoda Families. P. Bouchet and J.P. Rocroi (eds.) Malacología 47 (1-2): 241-266.

Brown, B. E., K. R. Clarke \& R.M. Warwick. 2002. Serial patterns of biodiversity change in coral across shallow reef flats in Ko Phuket, Thailand, due to the effects of local (sedimentation) and regional (climatic) perturbations. Marine Biology 141 : 21-129.

Capetillo, N., A. Lopeztegul, A. Betanzos \& R. Hernández. 2011. Variabilidad espacial y temporal de la abundancia del erizo de mar Lytechinus variegatus (Lamarck, 1816) en el Golfo de Batabanó, Cuba. Revista Cubana de Investigaciones Pesqueras 28(2): 52-58.

Cerdeira-Estrada, S. Lorenzo-Sánchez, S. A. Areces-Mallea \& C. MartínezBAYón. 2008. Mapping of the spatial distribution of benthic habitats in the Gulf of Batabanó using Lansad-7 images. Ciencias Marinas 34 (2): 213-222.

Снu, P. S. 2004. ENSO and tropical cyclone activity. In: Hurricanes and typhoons: past, present and future. Murnane, R.J., Liu, K.B. (Eds). Columbia University Press, New York, pp. 297-332.

Clarke, K. R \& R. N. Gorley. 2006. PRIMERv6: User manual/ tutorial. PRIMER-E, Plymouth.

Clarke, K. R \& R. M. Warwick. 1998. A taxonomic distinctness and its statistical properties. Journal of Applied Ecology 35: 523-531.

Clarke, K. R \& R. M. Warwick. 2001. A futher biodiversity index applicable to species lists: variation in taxonomic distinctness. Marine Ecology Progress Series 216: 265-278.

Emanuel, K. 2005. Increasing destructiveness of tropical cyclones over the past 30 years. Nature 436 : 686-688.

Espinosa, J. \& J. ORTEA. 1998. Nuevas especies de la Familia Marginellidae (Mollusca: Neogastropoda) de Cuba y los cayos de la Florida. Avicennia 8/9: 117-134.

Espinosa, J \& J. ORtea. 2001. Moluscos del Mar Caribe de Costa Rica: desde Cahuita hasta Gandoca. Avicennia, Suplemento 4: 1-77.

Espinosa, J \& J. ORTEA. 2003. Nuevas especies de moluscos marinos (MoIlusca: Gastropoda) del Parque Nacional Guanahacabibes, Pinar del Río, Cuba. Avicennia 16: 143-156.

Espinosa, J., J. Ortea, M. Caballero \& L. Moro. 2005. Moluscos marinos de la península de Guanahacabibes, Pinar del Río, Cuba, con la descripción de nuevos taxones. Avicennia 18: 1- 84.

Guerra García, R., M. E Chávez, K. Hernández \& E. Tristá. 2005. Cambios sedimentarios en la cuenca marina sur de la provincia Habana. Revista Ciencias de la Tierra y el Espacio 1 8: 35-44.

Halun. Z., T. J. Borum, J. Kamp-Nielsen, L. Duarte, C. M. \& M. D. Fortes. 2002. Experimental evaluation of the effects of siltation-derived changes in sediment conditions on the Philippine seagrass Cymo- 
docea rotundata. Journal of Experimental Marine Biology and Ecology $279: 73-87$.

Herbeck, L. S, D. Unger, U. Krumme, S. Mei Lu, T. C. Jennerjahn. 2011. Typhoon-induced precipitation impact on nutrient and suspended matter dynamics of a tropical estuary affected by human activities in Hainan, China. Estuarine, Coastal and Shelf Science 93: 375-388.

Hidalgo-Rodríguez, G \& A. Areces-Mallea. 2009. Estimación cualitativa y cuantitativa del macrozoobentos en la macrolaguna del Golfo de Batabanó, Cuba. Revista Cubana de Investigaciones Pesqueras 26 (1): 73-79.

Hong, Z., H. ER \& Z. Zhinan. 2010. Taxonomic Distinctness of Macrofauna as an Ecological Indicator in Laizhou Bay and Adjacent Waters. Journal of Ocean University of China 9: 350-358.

Hoskins, C. W. 1964. Molluscan biofacies in calcareous sediments, Gulf of Batabanó, Cuba. Bulletin of the American Association of Petroleum Geologist 48(10), 1680-1704.

Hua, E., Z. N. Zhang, Z. S. Yu \& Y. Zhang. 2010. Preliminary study on the inmediate response of the nematode community to Typhoon Soudelor. Deep-Sea Research II 57: 1064-1070.

IBARZÁBAL, D. 1990. Características de la macroinfauna de la macrolaguna del Golfo de Batabanó. In: El bentos de la macrolaguna del Golfo de Batabanó. Alcolado, P.M. (Ed.), Ediciones Academia, pp. 113-128.

IPCC. 2007. Climate Change 2007: IPCC fourth Assessment Report. Working Group I Report The Physical Science Basis IPCC, Geneva, Switzerland, $996 \mathrm{p}$.

Leonard, D. R. P., K. R. Clarke, P. J. Somerfield \& R. M. Warwick. 2006. The application of an indicator based on taxonomic distinctness for UK marine biodiversity assessments. Journal Environmental Management 78: 52-62.

MagurRan, A. E. 2004. Measuring biological diversity. Blackwell, 0xford. 70 p.

Maluin, M. A. \& C. A. Corbetr. 2006. How hurricane attributes determine the extent of environmental effects: multiple hurricanes and different coastal systems. Estuaries Coasts 29:1046-1061.

Martínez-Daranas, B., M. Cano-Mallo \& L. Clero-Alonso. 2009. Los pastos marinos de Cuba: estado de conservación y manejo. Serie Oceanológica 5: 24-44.

Martínez-Estalella, N \& P. M, Alcolado. 1990. Características generales de las comunidades de moluscos de la macrolaguna del Golfo de Batabanó. In: P.M Alcolado (Ed.) El bentos de la macrolaguna del Golfo de Batabanó. La Habana. Editorial Academia. pp. 53-74.

MikKeLSEN, P. M \& R. BieleR. 2008. Seashells of Southern Florida. Living marine mollusks of the Florida Keys and adjacent regions. Bivalves. Pricenton, University Press, 503 p.

Mouillot, D., S. Gaillard, C. Alaaume, M. Verlaque, T. Belsher \& M. TrousSELLIER. 2005. Ability of taxonomic diversity indices to discriminate coastal lagoon environments based on macrophyte communities. Ecological Indicators 5: 1-17.
ORTEA, J \& J. EsPInosa. 2001. Intelcysticus e Inbiocysticus (Mollusca: Neogastropoda: Cysticidea) dos nuevos géneros del Atlántico occidental tropical. Avicennia, 14: 107.114.

Peierls, B. L., R. R. Christian \& H. W. Paerl. 2003. Water quality and phytoplankton as indicators of hurricane impacts on a large estuarine ecosystem. Estuaries 26(5): 1329-1343.

Perigó, A. E., J. F. Montalvo, M. Martínez - Canals, 0. Ramírez, G. Suárez, J. Simanca, A. Perigó, C. Martínez, D.M. Pérez. 2005. Presiones Antropogénicas y su relación con la Calidad Ambiental de la Ecoregión del Golfo de Batabanó. Impactos y Respuestas. [http://www. redalyc.org/articulo.0a?id=181220525073] Fecha de consulta: 29 de agosto de 2015.

Puga, R., R. Piñelro, R. Alzugaray, L. S.Cobas, M. E de León \& 0. Morales. 2013. Integrating Anthropogenic and Climatic Factors in the Assessment of the Caribbean Spiny Lobster (Panulirus argus) in Cuba: Implications for Fishery Management. International Journal of Marine Science 3 (6): 36-45.

Rodríguez, D. A \& R. M. Claro. 2009. Impacts of hurricane lke on coral reef fishes in Santa Lucia tourist area, Camagüey, Cuba. Serie Oceanológica 5: 111-127.

Rosenberg, G., F. Moretzsohn \& E. F. García. 2009. Gastropoda (Mollusca) of the Gulf of Mexico. In: Tunnell, J. W. y Felder, D. L., (Eds.) Gulf of Mexico origin, waters and biota. Volume 1, Biodiversity pp. $579-699$.

Salazar-Vallejo, S. 2002. Huracanes y biodiversidad costera tropical. Revista Biología Tropical 50 (2): 415-428.

Turgeon, D. D., W. G. Lyons, P. Mikkelsen, G. Rosenberg \& F. Moretzsohn. 2009. Bivalvia (Mollusca) of the Gulf of Mexico. In: Tunnell, J. W. y Felder, D. L., (Eds.) Gulf of Mexico origin, waters and biota. Volume 1, Biodiversity pp. 711-744.

Valelel, I., P. Peckol, C. D’Avanzo, K. Lajtha, J. Kremer, W. R. Geyer, K. Forman, D. Hersh, B. Suly, T. Isaul \& R. Crawford. 1996. Hurricane Bob on Cape Cod. American Scientist 84: 154-165.

VImont, D. J. \& J. P. Kossin. 2007. The Atlantic meridional mode and hurricane activity. Geophysical Research Letters 34, L07709, doi: 10.1029/2007GL029683.

WARWick, R. M \& K. R. ClaRkE. 1995. New biodiversity measures reveal a decrease in taxonomic distinctness with increasing stress. Marine Ecology Progress Series 129: 301-305.

WaRWick, R. M \& K. R. ClaRke. 2001. Practical measures of marine biodiversity base on relatedness of species. Oceanography and Marine Biology: an Annual Review 39: 207-231.

Recibido: 16 de Julio de 2015.

Aceptado: 22 marzo de 2016. 